\title{
Effect of Nano ZnO on Growth and Yield of Finger Millet [Eleusine coracana (L.) Garten.]
}

\author{
Saraswathi $^{1 *}$, Y. Vishwanath Sheety ${ }^{1}$, M. Dinesh Kumar ${ }^{2}$ and K.T. Gurumurthy ${ }^{1}$ \\ ${ }^{1}$ Department of Soil Science and Agriculture Chemistry, College of Agriculture, \\ ${ }^{2}$ Department of Agronomy, College of Agriculture, University of Agricultural and \\ Horticultural Sciences, Shivamogga \\ *Corresponding author
}

\section{Keywords}

Nenotechnology,

Nanoscale, Chelated zinc sulphate, Zinc oxide, Nano fertilizer

\section{Article Info}

Accepted:

12 January 2019

Available Online:

10 February 2019

\section{A B S T R A C T}

With the growing limitation in arable land and water resources, the development of agriculture sector is only possible by increasing resources use efficiency with the minimum damage to agro ecology through effective use of modern technologies. Among these, nano technology has the potential to revolutionize agriculture system. An investigation was initiated to examine the effect of nano scale zinc oxide particle on plant growth and development. In view of the widespread cultivation of ragi in India and other parts of the globe and view of the potential influence of zinc on its growth, this crop was chosen as the model system. A pot culture experiment was conducted during Rabi 20162017 with the foliar application of nano scale zinc oxide particle at lower rate dose compared to the chelated zinc sulphate recommended and we recorded higher grain yield $\left(9.60 \mathrm{~g} \mathrm{plant}^{-1}\right)$ and straw yield $\left(15.87 \mathrm{~g} \mathrm{plant}^{-1}\right)$ in $\mathrm{T}_{7}$ which receive nano $\mathrm{ZnO} @ 500 \mathrm{ppm}$ $\mathrm{ha}^{-1}$ as foliar spray respectively, compared to chelated zinc sulphate. The inhibitory effect with the higher dose nano particle concentration (nano ZnO @ 1250 ppm) reveals the need for judicious usage of this particle in such application, this study show that the use of nano fertilizers causes an increase in nutrient use efficiency, reduces soil toxicity associated with over dosage and reduces the frequency of the application. Hence nanotechnology a high potential for achieving sustainable agriculture, especially in developing countries.

\section{Introduction}

Agriculture is the backbone of most developing countries, with more than $60 \%$ of the population reliant on it for their livelihood. Agricultural scientists are facing a wide spectrum of challenges such as stagnation in crop yields, low nutrient use efficiency, declining soil organic matter, multi-nutrient deficiencies, climate change, shrinking arable land and water availability and shortage of labor besides exodus of people from farming. In spite of immense constraints faced, we need to attain a sustainable growth in agriculture at the rate of $4 \%$ to meet the food security challenges. Therefore in the future, emphasis should be laid on production of high quality food with 
the required level of nutrients and proteins, (Pijls et al., 2009; Ghaly and alkoaik, 2010). The issue of micronutrient deficiency is related with food security Micronutrient deficiencies in human being as well as crop plants are difficult to diagnose and consequently the problem is termed as 'hidden hunger' (Stein et al., 2008). This hidden hunger may cause nearly $40 \%$ reduction in crop productivity among them Zinc ( $\mathrm{Zn}$ ) deficiency is most wide spread nutritional disorder. Most of the Indian soils are found to be $\mathrm{Zn}$ deficient, hence the food crops grown in those soils contain less amount of $\mathrm{Zn}$. In order to overcome $\mathrm{Zn}$ disorder, several strategies are being employed including supplementation, fortification, diversification and biofortification. Among these strategies biofortification of food crops with $\mathrm{Zn}$ is considered to be cheaper and sustainable.

To address these problems, there is a need to explore one of the frontier technologies such as 'Nanotechnology. It is a new emerging and interesting field of science is currently applied in many areas. It has great application in the field of agriculture. Nano particles (NPs) are commonly accepted as materials with at least two dimensions between 1-100 nm. "Nanotechnology is the art and science of manipulating matter at nanoscale. Because nano particles are spherical or faceted metal particles typically $<100 \mathrm{~nm}$ in size. These nano particles are having high surface area $(30-50 \mathrm{~m} 2 / \mathrm{g})$, high activity, better catalytic surface, rapid chemical reaction, rapidly dispersible and adsorb abundant water. So nano fertilizers may increase the efficiency of nutrient uptake, enhance yield and nutrient content in the edible parts and also minimize its accumulation in the soil. In view of the above facts the present study entitled Effect of nano $\mathrm{ZnO}$ particle on growth and Yield of Finger Millet (Eleusine coracana (L.) Garten.)

\section{Materials and Methods}

The present investigation was carried out at Zonal Agriculture and Horticultural Research Station, University of Agricultural and Horticultural Sciences (UAHS), Navile, Shivamogga to study the effect of Nano Zinc particle on growth and yield of finger millet in a pot culture experiment. The details regarding the collection of soil sample, methodology followed in the pot culture experiment and analytical methods employed during the course study for soil and plant analysis as per the standard procedure. Bulk soil samples collected from micro watershed in different land use system in kadur taluk of chikkamagalur district were categorized as low to medium with respect to native soil fertility status zinc nutrients. Surface soil samples to a depth of $30 \mathrm{~cm}$ were collected for the pot culture experimentation. The collected samples were characterized for various physical and chemical properties. Same sample used for pot culture experiment to study the growth and yield of finger millet. The experiment was laid out in a Complete Randomized design. With ten treatments involving various concentrations of nano $\mathrm{ZnO}$ and three replication with two sources used in these experiment one is Zinc oxide $(\mathrm{ZnO})$ nano particle which is having particle size of $50 \mathrm{~nm}$ and $\mathrm{ZnSO}_{4} .7 \mathrm{H}_{2} \mathrm{O}$ were used in the study. $\mathrm{ZnO}$ nanoparticles of mean size of 50 $\mathrm{nm}$ diameter were used in the study. Chelated bulk $\mathrm{ZnSO}_{4} \cdot 7 \mathrm{H}_{2} \mathrm{O}$ was used as a reference $\mathrm{Zn}$ source. Because bulk $\mathrm{ZnO}$ will not dissolve in water and plants cannot absorb it, farmers are widely using chelated $\mathrm{ZnSO}_{4} \cdot 7 \mathrm{H}_{2} \mathrm{O}$. The materials were suspended directly in deionized water and dispersed by ultrasonic vibration $(100 \mathrm{~W}, 40 \mathrm{KHz})$ for $30 \mathrm{~min}$. Magnetic bars were placed in the suspensions for stirring before use to avoid aggregation of the particles. The soil sample was thoroughly mixed with FYM and filled in pots of $20 \mathrm{~kg}$ capacity having hole on the corner of the 
bottom of the container. Nitrogen, Phosphorus and potash were added to each pot at the rate of $50,40,25 \mathrm{~kg} \mathrm{ha}^{-1}$, respectively using urea, SSP and MOP. Zinc was applied in the form of $\mathrm{ZnSO}_{4} .7 \mathrm{H}_{2} \mathrm{O}$ to treatments $\mathrm{T}_{3}$ and $\mathrm{T}_{5}$ for soil and foliar for $T_{4}$ and $T_{5}$ application, respectively. Whereas, foliar application of nano zinc oxide was done in T6 to T10 applied at time (30 DAT and 60 DAT) as per treatment details $\mathrm{T}_{1}$ : Absolute control, $\mathrm{T}_{2}$ : RPP, $\mathrm{T}_{3}$ : Soil application of $\mathrm{ZnSO}_{4} \cdot 7 \mathrm{H}_{2} \mathrm{O}$ @ $10 \mathrm{~kg} \mathrm{ha}^{-1}$ at sowing, $\mathrm{T}_{4}$ : Foliar $\mathrm{ZnSO}_{4} \cdot 7 \mathrm{H}_{2} \mathrm{O}$ @ $0.5 \% \mathrm{ha}^{-1}$ at 30 and $60 \mathrm{DAT}, \mathrm{T}_{5}$ : Both soil and Foliar application $\mathrm{ZnSO}_{4} .7 \mathrm{H} 2 \mathrm{O} @ 0.5 \%$ ha $^{-1}$ at 30 DAS, T6: Foliar Nano ZnO @ 100 ppm ha ${ }^{-1}, \mathrm{~T}_{7}$ : Foliar Nano ZnO @ 500 ppm ha $^{-1}, \mathrm{~T}_{8}$ : Foliar Nano ZnO @ 750 ppm ha $^{-1}$, T9:Foliar Nano ZnO @ 1000 ppm ha ${ }^{-1}$, $\mathrm{T}_{10}$ :Foliar Nano $\mathrm{ZnO} @ 1250$ ppm ha ${ }^{1}$.Periodical observations $(30,60$ at harvest DAT) on growth and yield parameters.

\section{Results and Discussion}

\section{Growth parameter}

In this study, results showed that the different forms of zinc sources they are $\mathrm{ZnSO}_{4} \cdot 7 \mathrm{H}_{2} \mathrm{O}$ as conventional fertilizers and nano $\mathrm{ZnO}$ significantly influenced the plant growth attributes of finger millet. Among the various treatments, application of NPK+FYM+ Soil and Foliar application $\mathrm{ZnSO}_{4} \cdot 7 \mathrm{H}_{2} \mathrm{O} @ 0.5 \%$ ha $^{-1}\left(\mathrm{~T}_{5}\right)$ recorded maximum plant height of $30.47 \mathrm{~cm}$ and minimum plant height of 18.50 $\mathrm{cm}$ were observed in control treatment $\left(\mathrm{T}_{1}\right)$ at tillering stage. At harvest stage the highest plant height was recorded in the treatment $\left(\mathrm{T}_{7}\right) 120.50 \mathrm{~cm}$ with the foliar application of nano $\mathrm{ZnO} @ 500$ ppm and control $\left(\mathrm{T}_{1}\right)$ treatment was recorded $85.00 \mathrm{~cm}$ in (Table 1 and Figure 1). This might be due to profound influence of Zinc fertilizers on height of plant as increased metabolic process in plant which has promoted meristamatic activities causing higher apical growth and photosynthetic area. The results are in agreement with the finding of (Dekhane et al, 2011). Number of leaves in finger millet also differed significantly at all the growth stages. However, there is an increase in number of leaves to foliar application of nano $\mathrm{ZnO}$ at harvest Treatment receiving foliar spray of nano $\mathrm{ZnO} @ 500$ ppm $\left(\mathrm{T}_{7}\right)$ recorded the highest number of leaves 42 and in control $\left(\mathrm{T}_{1}\right) \quad 25.00$ respectively (Table 1). Whereas, higher concentrations @ 1250 and 1000 ppm exhibited detrimental effects on growth of finger millet. (Prasad et al, 2012) observed that nano $\mathrm{ZnO}$ promoted seed germination, seedling vigor, early flowering and higher chlorophyll content in leaf. They also observed beneficial effects of NPs in enhancing plant growth, development and yield in peanut at lower doses, but at higher concentrations $\mathrm{ZnO}$ NPs were detrimental just as the bulk nutrients. Number of earheads of finger millet, the finger length and test weight were significantly high in treatment receiving fertilizer and FYM along with nano $\mathrm{ZnO}$ foliar spray@500 ppm, which was superior over all other treatments. The significant increase in test weight may be attributed to better grain filling due to improved nutrient supply (Table 2).

\section{Yield parameter}

The results of the study revealed that application of nano $\mathrm{ZnO}$ as foliar spray has recorded highest grain yield (9.60 gm plant ${ }^{-1}$ ) and least in control without application of fertilizers(7.00 gm plant ${ }^{-1}$ ) in Table 2. Nano particles (NPs) with small size and large surface area are expected to be the ideal material for use as a $\mathrm{Zn}$ fertilizer in plants. It is because of that when materials are transformed to a nano scale, they change their physical, chemical and biological characteristics as well as catalytic properties and even more increase the chemical and biological activities (Mazaherinia et al., 2010). 
Table.1 Effect of different levels of foliar application of $\mathrm{ZnSO}_{4} \cdot 7 \mathrm{H}_{2} \mathrm{O}$ and nano $\mathrm{ZnO}$ formulation at different growth stages on growth parameters of finger millet

\begin{tabular}{|c|c|c|c|c|c|c|}
\hline \multirow{2}{*}{$\begin{array}{l}\text { Treat. } \\
\text { No }\end{array}$} & \multirow[t]{2}{*}{ Treatment } & \multicolumn{3}{|c|}{ Plant height (cm) } & \multicolumn{2}{|c|}{ Number of leaves hill } \\
\hline & & $\begin{array}{l}\text { Tillering } \\
\text { stage }\end{array}$ & $\begin{array}{c}\text { Ear } \\
\text { head } \\
\text { stage }\end{array}$ & $\begin{array}{l}\text { Harvest } \\
\text { stage }\end{array}$ & $\begin{array}{l}\text { Tillering } \\
\text { stage }\end{array}$ & $\begin{array}{l}\text { Harvest } \\
\text { stage }\end{array}$ \\
\hline $\mathbf{T}_{1}$ & Absolute control & 18.50 & 57.00 & 85.00 & 18.00 & 25.00 \\
\hline $\mathbf{T}_{2}$ & RPP (Recc NPK +FYM) & 23.00 & 60.50 & 100.00 & 20.00 & 28.00 \\
\hline $\mathbf{T}_{3}$ & $\begin{array}{l}\text { NPK+FYM +Soil application ZnSO4.7H2O @ } 10 \mathrm{~kg} \mathrm{ha}^{-1} \text { at } \\
\text { sowing }\end{array}$ & 27.00 & 65.42 & 96.00 & 29.00 & 30.00 \\
\hline $\mathbf{T}_{4}$ & $\begin{array}{l}\text { NPK+FYM+ Foliar ZnSO4.7H2O @ } 0.5 \% \text { ha }^{-1} \text { at } 30 \text { and } 60 \\
\text { DAT }\end{array}$ & 25.00 & 66.00 & 97.43 & 25.00 & 32.00 \\
\hline $\mathbf{T}_{5}$ & $\begin{array}{l}\text { NPK+FYM+ Soil and Foliar application ZnSO4.7H2O @ } 0.5 \% \\
\text { ha }^{-1}\end{array}$ & 30.47 & 67.00 & 110.00 & 30.00 & 38.00 \\
\hline $\mathbf{T}_{6}$ & $\begin{array}{l}\text { NPK + FYM +Foliar Nano ZnO @ } 100 \text { ppm ha }{ }^{-1} \text { at } 30 \text { and } 60 \\
\text { DAT }\end{array}$ & 20.60 & 62.55 & 99.00 & 25.00 & 29.00 \\
\hline $\mathbf{T}_{7}$ & NPK +FYM +Foliar Nano ZnO @ 500 ppm ha ${ }^{-1} 30$ and 60 DAT & 26.00 & 70.00 & 120.50 & 28.00 & 42.00 \\
\hline $\mathbf{T}_{8}$ & $\begin{array}{l}\text { NPK+ FYM+ Foliar Nano ZnO @ } 750 \text { ppm ha }{ }^{-1} \text { at } 30 \text { and } 60 \\
\text { DAT }\end{array}$ & 25.00 & 69.00 & 105.00 & 28.00 & 41.00 \\
\hline $\mathbf{T}_{9}$ & $\begin{array}{l}\text { NPK+ FYM + Foliar Nano ZnO @ } 1000 \text { ppm ha }^{-1} \text { at } 30 \text { and } 60 \\
\text { DAT }\end{array}$ & 23.00 & 60.00 & 89.56 & 27.00 & 39.00 \\
\hline \multirow[t]{4}{*}{ T10 } & $\begin{array}{l}\text { NPK + FYM + Foliar Nano ZnO @ } 1250 \mathrm{ppm} \mathrm{ha}^{-1} \text { at } 30 \text { and } 60 \\
\text { DAT }\end{array}$ & 19.00 & 58.00 & 85.56 & 25.00 & 35.00 \\
\hline & S.Em+ & 0.61 & 0.66 & 1.13 & 0.58 & 0.65 \\
\hline & C.D @1\% & 2.41 & 2.65 & 4.53 & 2.32 & 2.61 \\
\hline & CV & 4.35 & 1.77 & 1.96 & 3.46 & 2.73 \\
\hline
\end{tabular}


Table.2 Effect of different levels of foliar application of $\mathrm{ZnSO}_{4} \cdot 7 \mathrm{H}_{2} \mathrm{O}$ and nano $\mathrm{ZnO}$ formulation at different growth stages on grain and straw yield of finger millet

\begin{tabular}{|c|c|c|c|}
\hline \multirow{2}{*}{$\begin{array}{c}\text { Treat. } \\
\text { No }\end{array}$} & \multirow{2}{*}{ Treatment } & Grain yield & Straw yield \\
\hline & & \multicolumn{2}{|c|}{ gm pot ${ }^{-1}$} \\
\hline $\mathbf{T}_{1}$ & Absolute control & 7.00 & 11.25 \\
\hline $\mathbf{T}_{2}$ & RPP (Recc NPK +FYM) & 7.60 & 12.10 \\
\hline $\mathbf{T}_{3}$ & Soil applicationZnSO4.7H2O @ $0.5 \%$ at sowing ha ${ }^{-1}$ & 7.85 & 12.63 \\
\hline $\mathbf{T}_{4}$ & Foliar ZnSO4.7H2O @ $0.5 \% \mathrm{ha}^{-1}$ at 30and $60 \mathrm{DAT}$ & 7.84 & 12.87 \\
\hline $\mathbf{T}_{5}$ & Soil and Foliar application ZnSO4.7H2O @ $0.5 \% \mathrm{ha}^{-1}$ & 8.40 & 14.77 \\
\hline $\mathbf{T}_{6}$ & Foliar Nano ZnO @ $100 \mathrm{ppm} \mathrm{ha}^{-1}$ at 30 and $60 \mathrm{DAT}$ & 7.35 & 12.16 \\
\hline $\mathbf{T}_{7}$ & Foliar Nano ZnO @ $500 \mathrm{ppm} \mathrm{ha}^{-1}$ at 30 and 60 DAT & 9.60 & 15.87 \\
\hline $\mathbf{T}_{8}$ & Foliar Nano ZnO @ $750 \mathrm{ppm} \mathrm{ha}^{-1}$ at 30 and 60 DAT & 9.30 & 15.40 \\
\hline $\mathbf{T}_{9}$ & Foliar Nano ZnO @ $1000 \mathrm{ppm} \mathrm{ha}^{-1}$ at 30 and 60 DAT & 7.60 & 11.53 \\
\hline \multirow[t]{4}{*}{$\mathbf{T}_{10}$} & Foliar Nano ZnO@1250 ppm ha ${ }^{-1}$ at 30 and 60 DAT & 7.40 & 11.04 \\
\hline & SEm \pm & 0.34 & 0.41 \\
\hline & C.D@1\% & 1.36 & 1.65 \\
\hline & CV & 7.78 & 5.43 \\
\hline
\end{tabular}

Fig.1 Plant height as influenced by different foliar application of $\mathrm{ZnSO}_{4} \cdot 7 \mathrm{H}_{2} \mathrm{O}$ and nano $\mathrm{ZnO}$ formulation at different growth stages of finger millet

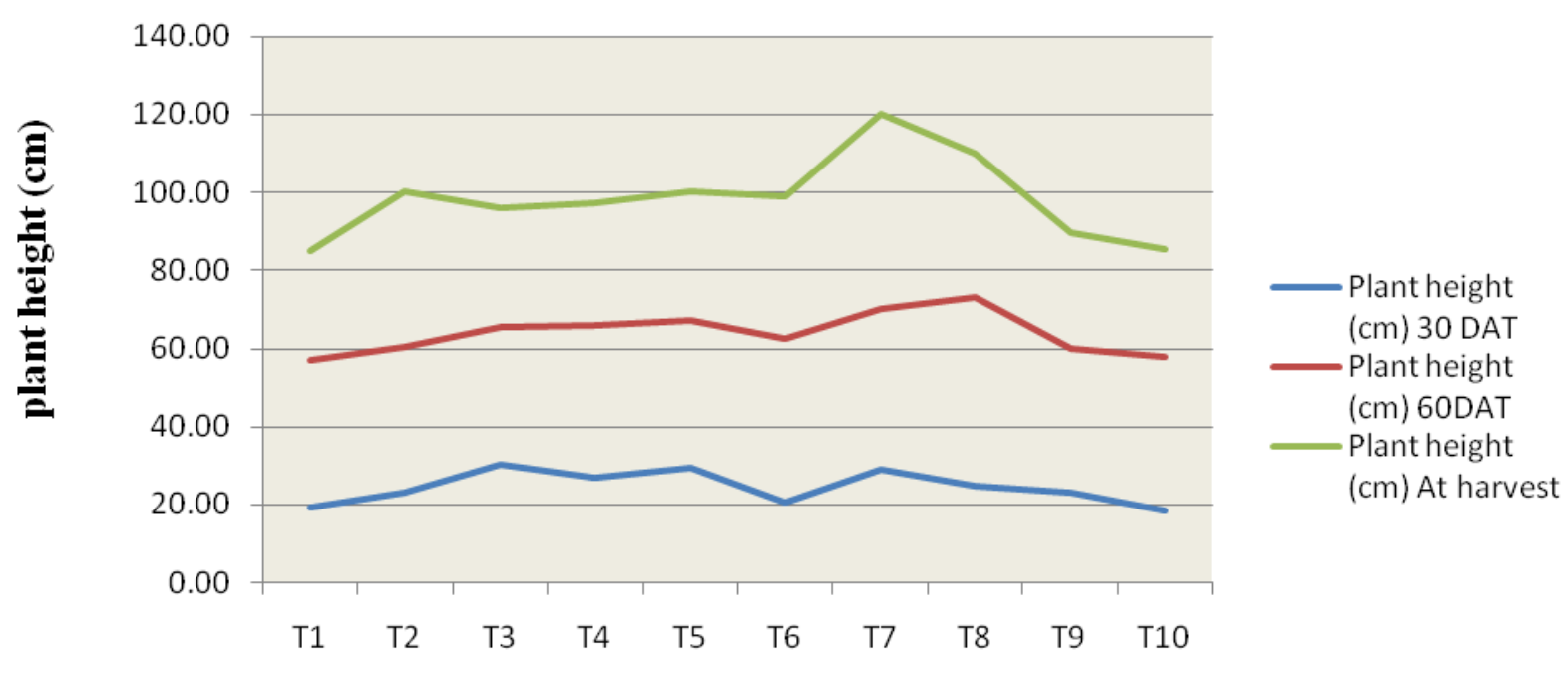

Treatments

$\mathrm{T}_{1: \text { Absolute control }}$

$\mathrm{T}_{2}$ RPP $($ Recc NPK +FYM)

$\mathrm{T}_{3:}$ Soil application $\mathrm{ZnSO} 4.7 \mathrm{H}_{2} \mathrm{O} @ 10 \mathrm{~kg} / \mathrm{ha}$ at sowing

$\mathrm{T}_{4}$ Foliar $\mathrm{ZnSO} 4.7 \mathrm{H}_{2} \mathrm{O} @ 0.5 \%$ at 30 and 60 DAT

$\mathrm{T}_{5:}$ Soil and Foliar application $\mathrm{ZnSO} 4.7 \mathrm{H}_{2} \mathrm{O}$ @ $0.5 \%$
T: Foliar Nano ZnO @ 100 ppm ha $^{-1}$ at 30 and 60 DAT

$\mathrm{T}_{7:}$ Foliar Nano ZnO @ 500 ppm ha $^{-1} 30$ and 60 DAT

$\mathrm{T}_{8}$. Foliar Nano ZnO @ $750 \mathrm{ppm} \mathrm{ha}^{-1}$ at 30 and $60 \mathrm{DAT}$

$\mathrm{T}_{9}:$ Foliar Nano ZnO @ $1000 \mathrm{ppm} \mathrm{ha}^{-1}$ at 30 and 60 DAT

$\mathrm{T}_{10}$ Foliar Nano ZnO @ $1250 \mathrm{ppm} \mathrm{ha}^{-1}$ at 30 and 60 DAT 
Prasad et al., (2012) studied the effect of nanoscale zinc oxide on the germination, growth and yield of peanut and observed significantly more growth and yield. Reynolds (2002) demonstrated that micronutrients in the form of NPs can be used in crop production to increase yield.

There was a promontory effect on dry matter production with the application of nano $\mathrm{ZnO}$ with @ 500 ppm. There after inhibitory effect was noticed. Based on the results, the highest

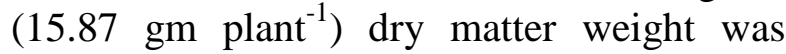
recorded in the treatment $\left(\mathrm{T}_{7}\right)$ receiving nano $\mathrm{ZnO} @ 500$ ppm and lowest were in control (11.25 gm plant $\left.{ }^{-1}\right)$. Improvement in growth parameters like plant height, number of leaves and leaf area per plant due to foliar application of nano $\mathrm{ZnO}$ resulted in increased dry matter accumulation (Table 2). Total biomass or crop dry weight (CDW) is the result of these two processes. Harvest index (HI) is the ratio of grain yield to biological yield, i.e., a measure of the efficiency of the plant when accumulating assimilates in the organs of economic significance (Moragues et $a l ., 2006)$. Significant relationships between yield and biomass at anthesis or during grain filling have been reported in bread wheat (Turner, 1997) and durum wheat (Ramdani, 2004).

In conclusion, application of nanotechnology in agriculture is still in its budding stage. However, it has the potential to revolutionize agricultural systems particularly where the issues on fertilizer applications are concerned. Nano fertilizer application promoted the growth, development, and has the potential to improve crop production and plant nutrition with greater effectiveness and agronomic efficiency compared to traditional sources of fertilizers. A new class of nano $\mathrm{ZnO}$ fertilizers to enhance the growth and yield of finger millet through pot culture test in an inert growing medium showed that application of nono $\mathrm{ZnO}$ by foliar application with lower dose as zinc sources promoted higher finger millet growth rate than regular $\mathrm{ZnSO}_{4} .7 \mathrm{H}_{2} \mathrm{O}$ fertilizer treatment. This research indicated that nano $\mathrm{ZnO}$ in enhancing grain yield and biomass production. The outcome of this research would be beneficial for other studies involving the application of nanotechnology in the field of agriculture.

\section{References}

Ghaly, A. E. and Alkoaik, F. N., 2010, Extraction of protein from common plant leaves for use as human food. American J. App Sci. 7: 331-342.

Mazaherinia, S., Astaraei, A. R., Fotovat, A. and Monshi, A., 2010, Nano iron oxide particles efficiency on Fe, Mn, Zn and $\mathrm{Cu}$ concentrations in wheat plant. Word App Sci J. 7(1):36-40.

Moragues, M., Garci, A., Del Moral, L. F., Moralejo, M. and Royo, C. 2006, Yield formation strategies of durum wheat landraces with distinct pattern of dispersal within the Mediterranean basin II. Biomass production and allocation. Field Crops Res., 95:182 193.

Pijls, L., Ashwell, M. and Lambert, J., 2009, EURRECA-A network of excellence to align European micronutrient recommendations. Food Chemistry. 113:748-753.

Prasad, T. N. V. K. V., Sudhakar, P., Sreenivasulu, Y., Latha, P., Munaswamy, V., Raja, K., Reddy, Sreeprasad, T. S., Sajanlal, P.R., Pradeep, T., 2012, Effect of nanoscale zinc oxide particles on the germination, growth and yield of peanut. J Plant Nutri., 35: 905- 927.

Ramdani, A., 2004, Impact of Spanish and Italian breeding activities on durum wheat yield and associated morpho- 
physiological and quality traits throughout the 20th century. Ph.D. Thesis. Department de Produccio`Vegetal i Cie`ncia Forestal, Universitat de Lleida, Lleida, Spain.

Reynolds, G.H., 2002, forward to the future nanotechnology and regulatory policy. Pacific Research Institute. 24: 1-23.
Stein, A.J., Meenakshi, J. V., Qaim, M., Nestel, P. and Sachdev, H. P. S., 2008, Potential impacts of iron biofortification in India. Soc. Sci. Med. 66: 1797-1808.

Turner, N.C. 1997, Further progress in crop water relations. Adv. Agron., 58: 293 338.

\section{How to cite this article:}

Saraswathi, Y. Vishwanath Sheety, M. Dinesh Kumar and Gurumurthy, K.T. 2019. Effect of Nano $\mathrm{ZnO}$ on Growth and Yield of Finger Millet Eleusine coracana (L.) Garten.). Int.J.Curr.Microbiol.App.Sci. 8(02): 1365-1371. doi: https://doi.org/10.20546/ijcmas.2019.802.160 